\title{
Concrete Formulation Study for Informal and Semi-Informal Construction Sectors
}

\author{
Narcisse Malanda ${ }^{1 *}$, Paul Louzolo-Kimbembe ${ }^{1,2}$, Louis Ahouet ${ }^{1,3}$, Jarlon Brunel Makela1, \\ Guy-Richard Mouengue ${ }^{3}$
}

\author{
${ }^{1}$ National Polytechnic High School, Marien Ngouabi University, Brazzaville, Congo \\ ${ }^{2}$ Normal High School, Marien Ngouabi University, Brazzaville, Congo \\ ${ }^{3}$ Building and Public Works Control Office, Brazzaville, Congo \\ Email: *nar6malanda@gmail.com, ${ }^{*}$ narcisse.malanda@umng.cg
}

How to cite this paper: Malanda, N., Louzolo-Kimbembe, P., Ahouet, L., Makela, J.B. and Mouengue, G.-R. (2019) Concrete Formulation Study for Informal and SemiInformal Construction Sectors. Open Journal of Civil Engineering, 9, 57-79. https://doi.org/10.4236/ojce.2019.91005

Received: December 16, 2018

Accepted: March 26, 2019

Published: March 29, 2019

Copyright (C) 2019 by author(s) and Scientific Research Publishing Inc. This work is licensed under the Creative Commons Attribution International License (CC BY 4.0).

http://creativecommons.org/licenses/by/4.0/

\begin{abstract}
The present work consisted in carrying out a study on the effective formulation of concrete for an optimal resistance to compression $\left(\mathrm{fc}_{28}\right)$ between 20 and $30 \mathrm{MPa}$ for the sites animated by the actors of the informal and semi-informal sectors of the construction. Studies have been carried out on projects under construction, by taking samples of fresh concrete in order to evaluate their real compressive strengths. These surveys show that there is a problem in the concrete formulation, as nearly $2 / 3$ of the results show the lack of technical knowledge on concrete formulation practices. Indeed, on eight sites surveyed and whose fresh concrete samples were taken, only two sites (7 and 8$)$ report fairly consistent results. Their 28-day compressive strength values are respectively 35.36 and $22.18 \mathrm{MPa}$. In addition, various formulations proposed with aggregates from different quarries or extracts from the bed of the Congo River, were determined in the laboratory. This study allowed us to obtain fairly objective results overall, which is characteristic of concretes of required quality. Of the six (06) formulation proposals, average resistances of $19.6 \mathrm{MPa}$ at 07 days and $25.28 \mathrm{MPa}$ at 28 days were obtained. These results at 28 days are in the range of 20 to $30 \mathrm{MPa}$, set as objective in this study. These formulations can be a reliable source for concrete manufacturers in these construction sectors. Similarly, the statistical study based on principal component factor analysis tests has shown that the most appropriate formulation, in terms of mechanical resistance, is that proposed with sand extracted from the Congo River (formulation 3 ). This is justified by the fact that this sand is consistent and has a good granular distribution.
\end{abstract}

\section{Keywords}

Formulation, Concretes, Aggregates, Cement, Physico-Mechanical 
Characteristics, Informal and Semi-Formal Sectors

\section{Introduction}

The act of building has become much more intense nowadays not only because of phenomena related to the accelerated urbanization of cities, but also in order to meet a pressing need, that of the building of basic infrastructure by public authorities or private partners, for the benefit of the population. In developing countries (DCs), there is a strong need for quality works. The real estate sector, for example, is characterized by a remarkable imbalance compared to the current pace of housing production. We are witnessing a development of "self-construction" in the construction of individual houses, and even other public infrastructures. This sector is the one that can be described as informal or semi-informal construction. In some countries, these sectors contribute about $90 \%$ of the production of habitat [1]. In accordance with this growth, many technical problems arise in the field of construction. Many technical deficiencies are noted, especially in the formulation of concrete. It is noted that nearly six (6) billions cubic meters of concrete per year are produced worldwide, since the resources needed for its manufacture exist in many countries and in large quantities. Also, this justifies the fact that this manufactured material is the most used in the world [2]. If the formulation of a concrete can be understood as the process of selection of constituents (aggregates, cement, additives) and their proportions optimal to manufacture a complex possessing certain required properties (consistency, resistance, durability...), it is nonetheless true to note that this is still done for the most part empirically, whereas there are more rational scientists [3]. Also, in these sectors of construction where self-construction predominates, the quality assurance of the works is not often appropriate, due to the lack of control of the appropriate technology for the realization of the works. Indeed, the reality is that in developing countries (DCs), the formulation of common concrete is subject to many hazards to the point where the durability of the structures made of concrete suggests a doubt in the consistency of the work. Thus, we observe the appearance of cracks and many disorders in the structures made from the first moments of exploitation thereof. Of course, concrete is a mixture the composition of which has an influence on its mechanical characteristics. But if they are less critical, the development of a suitable concrete may then be unreliable. This measures the importance of the study on the formulation of concrete, all the more necessary as the required characteristics are demanding.

The new construction techniques require a maximum reliability of the structure vis-à-vis the natural hazards such as natural disasters, dynamic solicitations or others. On the other hand, in addition to the ultimate compressive strength, these concretes must meet many specifications relating to rheological properties, early age characteristics, deformation properties and durability aspects [4] [5] et 
[6]. However, Packa's (2015) surveys in the Republic of Congo of concrete formulation methods in some Congo cities, namely Brazzaville, Ouesso and PointeNoire, have shown that the companies identified for this survey make greater use of the process. From the capacity of the wheelbarrow (50 to 60 liters) and the weight of the cement bag (50 kg), this empirical process is called a wheelbarrow "BS". However, these professionals hardly use the known classical and scientific methods (Faury, Vallette, Bolomey, Dreux-Gorisse...). Indeed, this survey reveals that $66 \%$ of professionals in these sectors in Brazzaville use the "BS" process, $85 \%$ in Pointe-Noire and $100 \%$ in the city of Ouesso in the northern part of the Congo [7].

On the other hand, from the point of view of concrete reliability, the studies carried out by Castaldo et al. (2018) on the evaluation of the partial safety factor related to the uncertainties of the overall strength model of reinforced concrete structures, showed evidence of a plastic behavior of the concrete in traction which leads to a very high coefficient of variation. The influence of numerical model uncertainty in describing the behavior of reinforced concrete elements was highlighted. Thus, the safety factor must be greater than one (01), this to avoid any early structural failure with physico-mechanical quality of strongly supported material [8].

Similarly, in the requirement for quality concrete, the influence of uncertainties related to materials and resistance models in the reliability-based calibration of resistance models makes reference to the design formulation of the supporting structures which must be compotated at both the service limit state and the ultimate limit state [9]. Moreover, reinforced concrete structures are also often attacked by degradation or aging effects when they are implanted in an aggressive environment; their durability is thus put into question. Indeed, through the Castaldo approach (2018), we can make predictability in the structural design by making the structure less vulnerable to the concrete degradation process, if at least the absolute tightness of the material can be obtained because of its porous nature. However, in such an environment, such as saline or sulphate media, the durability induced by the transfer properties of the material, takes on an obvious character; it can lead to premature degradation of the material (concrete) resulting in the correction of steels and the leaching of concrete [10] [11] [12] [13].

Therefore, this work proposes to carry out a study on the concrete formulation with technical constraint, to obtain an estimated compressive strength between 20 and $30 \mathrm{MPa}$, to use in the informal and semi-informal sectors of the construction, with the materials collected locally in the region of Brazzaville. It is therefore to propose different formulations by combining various materials from several quarries or the Congo River.

\section{Material and Methods}

\section{Investigation and sampling of fresh concrete on construction sites}

The study was initially based on a site survey in 2016 to test fresh concrete. 
The surveys consisted of taking samples of fresh concrete (bastard concrete) in cubic or cylindrical molds on various sites in progress and identified in Brazzaville.

The evolution of the mechanical characteristics of these concretes has been monitored in the laboratory. Also, to reduce some of the results of cubic sample resistances to cylindrical samples, we used the relation $\delta c y l / \delta c u b$, linking the resistances obtained on cubic and cylindrical samples according to the approach of Dreux-Gorris (1983) [14] [15]. A total of eight (08) samples of fresh concrete were collected from eight (08) different sites and one (01) sample type of concrete was made at the Office of Building Control and Public Works (BCBTP), called sample control.

Mechanical analysis of fresh concrete sampled (standards NF EN 12350-1, NF EN 12390-3, NF EN 206-1)

The aggregates consist of gravel, sand from the Congo River or the Djiri quarry, with a certain amount of mixing water. Mixing and vibration are often done manually. The data for the materials used, including the geographical coordinates of the work in progress are presented in Table 1. The materials used for the manufacture of these concretes according to the cases are presented in Table 2.

Tests and experimentation in the laboratory

The concrete samples taken from the eight (8) sites were placed in cylindrical and cubic molds. These samples are then tested at 7, 14, 21 and 28 days (sites 2, 3,4 and 7) for the determination of compression characteristics and then tested at 7 and 28 days for sites 1, 5, 6 and 8 in view of the difficulties related to the activity even in the said sites (Figures 1-4).

Simple compression test of concrete (NF EN 12350-1 standard, NF EN 12390-3 April 2012; NFP15-403)

For this test, cylindrical $(16 \times 32 \mathrm{H})$ or cubic $(15 \times 15 \times 15)$ samples were prepared.

Table 1. Materials used in the sites visited (Brazzaville).

\begin{tabular}{|c|c|c|c|c|c|c|c|}
\hline Construction sites & Cement types & Gravel classes & Origin of sand & $\begin{array}{l}\text { Quantity } \\
\text { of water }\end{array}$ & $\begin{array}{l}\text { Mixing of } \\
\text { concrete }\end{array}$ & Latitude & Longitude \\
\hline $\begin{array}{c}\text { Shipyard 0: } \\
\text { Sample Control sample }\end{array}$ & CEM II 42.5R & $5 / 10$ et $12.5 / 25$ & Crushed & Variable & Manual & - & - \\
\hline Shipyard 1 & CEM II 42.5 & $3.15 / 12.5$ & Congo River & Variable & Manual & $4^{\circ} 17^{\prime} 44.0^{\prime \prime S}$ & $15^{\circ} 14^{\prime} 35.7^{\prime \prime} \mathrm{E}$ \\
\hline Shipyard 2 & CEM II 42.5R & $5 / 25$ & Concassé & Variable & Manual & $4^{\circ} 17^{\prime} 02.8^{\prime \prime S}$ & $15^{\circ} 15^{\prime} 20.6^{\prime \prime} \mathrm{E}$ \\
\hline Shipyard 3 & CEM II 32.5R & $5 / 16$ et $12.5 / 25$ & Congo River & Variable & Manual & $4^{\circ} 17^{\prime} 41.1^{\prime \prime S}$ & $15^{\circ} 15^{\prime} 20.5^{\prime \prime} \mathrm{E}$ \\
\hline Shipyard 4 & CEM II 32.5R & $5 / 31.5$ & Congo River & Variable & $\begin{array}{c}\text { Manual + } \\
\text { adjuvant }\end{array}$ & $4^{\circ} 14^{\prime} 55.3^{\prime \prime} \mathrm{S}$ & $15^{\circ} 16^{\prime} 23.5^{\prime \prime} \mathrm{E}$ \\
\hline Shipyard 5 & CEM II 42.5R & $5 / 31.5$ & Djiri quarry & Variable & Manual & $4^{\circ} 14^{\prime} 56.4^{\prime \prime S}$ & $15^{\circ} 16^{\prime} 13.8^{\prime \prime} \mathrm{E}$ \\
\hline Shipyard 6 & CEM II 42.5R & $5 / 25$ & Congo River & Variable & Manual & $4^{\circ} 14^{\prime} 57.1^{\prime \prime S}$ & $15^{\circ} 16^{\prime} 13.5^{\prime \prime} \mathrm{E}$ \\
\hline Shipyard 7 & CEM II 42.5R & $5 / 25$ & Djiri quarry & Variable & concrete mixer & $4^{\circ} 15^{\prime} 29.0^{\prime \prime S}$ & $15^{\circ} 15^{\prime} 54.4^{\prime \prime} \mathrm{E}$ \\
\hline Shipyard 8 & CEM II 42.5R & $3.15 / 10$ et $12.5 / 25$ & Congo River & Variable & $\begin{array}{l}\text { concrete mixer } \\
+ \text { adjuvant }\end{array}$ & $4^{\circ} 16^{\prime} 28.5^{\prime \prime S}$ & $15^{\circ} 17^{\prime} 10.1^{\prime \prime} \mathrm{E}$ \\
\hline
\end{tabular}




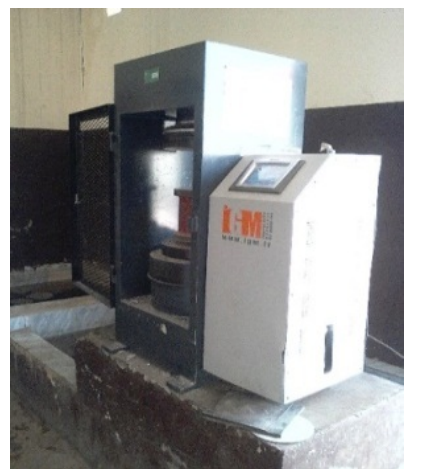

Figure 1. IGM Electronic Concrete Baler.

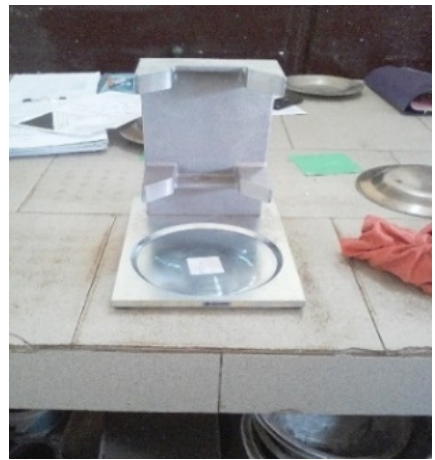

Figure 2. Surfacing square for concrete specimen, PROVITEQ type.

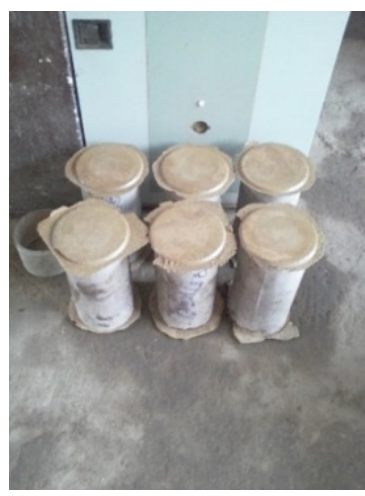

Figure 3. Surfaced specimens.

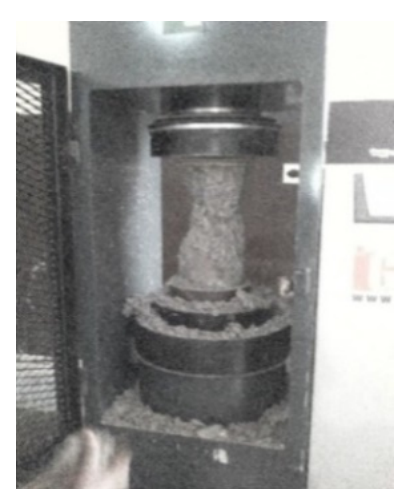

Figure 4. Specimen subjected to compression. 
Materials used

- An electronic concrete press (Figure 4)

- An electronic scale

- A surfacing device (Figure 5)

- Sulfur

- A trowel

- A pot (for driver suffers it)

- A hotplate

Procedure (NF EN 12390-2)

After setting and curing the cement, the test pieces are demolded and immersed in water. These specimens are then removed and dried 24 hours before the test, for each age $(7,14,21$ and 28 days). Then we weigh them to know the weight of each specimen, and we proceed to surfacing (Figure 5) from liquefied sulfur through a hot plate, because a non-surfaced test piece loses $10 \%$ to $15 \%$ of its resistance.

The specimen previously surfaced (Figure 6) is placed and centered on the hydraulic press (Figure 7) along its vertical axis between two discs (upper and lower) of the press. The lower disk is subjected to an upward movement and the value of the breaking load expressed in $\mathrm{KN}$ is read from the electronic board of the press.

\section{Method of Concrete Formulation}

Obtaining the characteristics required for concrete requires imperatively adopting and optimizing its formulation to the requirements appropriate to the structure and its environment. This is why the process usually involves two phases; the approach of a composition (from the Dreux-Gorisse method) where the search for maximum compactness (workability) is required, and the experimental fitting approach of this formulation (laboratory convenience tests), [14] [15] and [5].

On the other hand, all the physicomechanical properties of aggregates including densities, sand equivalent, micro-deval test, specific gravity, particle size analysis, metric finesse module, Los Angeles test, the tests on the cement, the curves of mixture..., were determined according to the standards in force by Makela (2016), [16]. Our formulations were carried out according to the Dreux-Gorisse method for a current concrete dosed at $350 \mathrm{~kg} / \mathrm{m}^{3}$.

The method consists in determining, according to the maneuverability criteria, the resistance of the parameters fixed in the specifications, the nature and the quantities of materials necessary for the manufacture of a cubic meter of concrete. It develops in five (05) steps, including the determination of the break curve, the compactness, the absolute volume of the cement, the masses of each granulate and the theoretical density of each material. These concretes meet the following characteristics: cement dosage: $350 \mathrm{~kg} / \mathrm{m}^{3}$; the type of cement: CEM II 42.5; the maximum diameter of aggregates: $25 \mathrm{~mm}$; vibration: normal; the slump at the Abram cone searched for: $6 \mathrm{~cm}$ (plastic concrete); the desired compressive 
strength at 28 days of age for cylindrical mold $(16 \times 32 \mathrm{H}), 20$ to $30 \mathrm{MPa}$.

Six (6) concrete formulation variants were examined with the aim of finding a formulation that meets the requirements of a quality concrete and the materials available in the different quarries (Table 2).

\section{Results and Analysis}

\section{Results and interpretation of fresh concrete collected in situ}

The results of the characteristic compressive strengths at d-days obtained after crushing of the specimens of the concretes are presented according to Figure 5 and Figure 6.

The results in these Figure 5 and Figure 6 show that:

- The control sample (Site 0) has a mean concrete compressive strength of 25.07 MPa obtained at 28 days of age. This concrete is characteristic of a concrete of required quality because it corresponds to a concrete of normal type whose values vary between $20 \mathrm{MPa}$ and $25 \mathrm{MPa}$. It can therefore be used as support for the load-bearing elements in the construction;

- The sites 5, 3 and 2 respectively have average compressive strengths of 14.13 $\mathrm{MPa}, 13.38 \mathrm{MPa}$ and 13.73 $\mathrm{MPa}$ obtained at 28 days of age. These concretes are not in conformity;

- Sites 6 and 8 have mean concrete compressive strengths of $19.05 \mathrm{MPa}$ and $22.18 \mathrm{MPa}$, respectively, at 28 days of age. These concretes are characteristic of concretes of acceptable quality, which corresponds to concretes of normal type. the concrete of site 6 having a value of $19.05 \mathrm{MPa}$ can be corrected although it is below $20 \mathrm{MPa}$;

- Sites 1 and 4 respectively have average compressive strengths of $6.22 \mathrm{MPa}$ concrete and $9.16 \mathrm{MPa}$ obtained at 28 days of age. These concretes are characteristic

Table 2. Classification of materials for six formulations.

\begin{tabular}{|c|c|c|c|c|}
\hline & $\mathbf{N}^{\bullet}$ & Sand & Gravel & Cement \\
\hline Formulation & 1 & White quarry sand of Djiri & $\begin{array}{l}\text { Crushed gravel of Kombé } \\
\text { - } \mathrm{G}_{1}(3.15 / 16) \\
\text { - } \mathrm{G}_{2}(12.5 / 25)\end{array}$ & CEM II 42.5 \\
\hline Formulation & 2 & Djiri white sand & $\begin{array}{l}\text { Crushed gravel } \\
\text { - } 50 \% \text { mixture of } \mathrm{G}_{1}(3.15 / 16) \\
\text { - } 50 \% \text { of } \mathrm{G}_{2}(12.5 / 25)\end{array}$ & CEM II 42.5 \\
\hline Formulation & 3 & Red sand from the Congo River collected in Brazzaville & $\begin{array}{l}\text { Crushed gravel } \\
\text { - } \mathrm{G}_{1}+\mathrm{G}_{2}(5 / 25) \text {. }\end{array}$ & CEM II 42.5 \\
\hline Formulation & 4 & $\begin{array}{l}\text { Djiri white sand }+ \text { crushed } 0 / 4 \text { Kombé enhanced sand (taking } \\
70 \% \text { of Djiri's white sand and } 30 \% \text { of crushed sand } 0 / 4 \text { ) }\end{array}$ & $\begin{array}{l}\text { Crushed gravel } \\
\text { - } \mathrm{G}_{1}(3.15 / 16) \\
\text { - } \mathrm{G}_{2}(12.5 / 25)\end{array}$ & CEM II 42.5 \\
\hline Formulation & 5 & $\begin{array}{l}\text { Red sand from the Congo River }+ \text { crushed sand } 0 / 4 \text { ( } 70 \% \\
\text { Congo River sand and 30\% crushed 0/4 sand) }\end{array}$ & $\begin{array}{l}\text { Crushed gravel } \\
\text { - } \mathrm{G}_{1}(3.15 / 16) \\
\text { - } \mathrm{G}_{2}(12.5 / 25)\end{array}$ & CEM II 42.5 \\
\hline Formulation & 6 & Crushed sand 0/5 & $\begin{array}{l}\text { Crushed gravel } \\
\mathrm{G}_{1}(3.15 / 16) \text { and } \mathrm{G}_{2}(12.5 / 25) \text {. }\end{array}$ & CEM II 42.5 \\
\hline
\end{tabular}




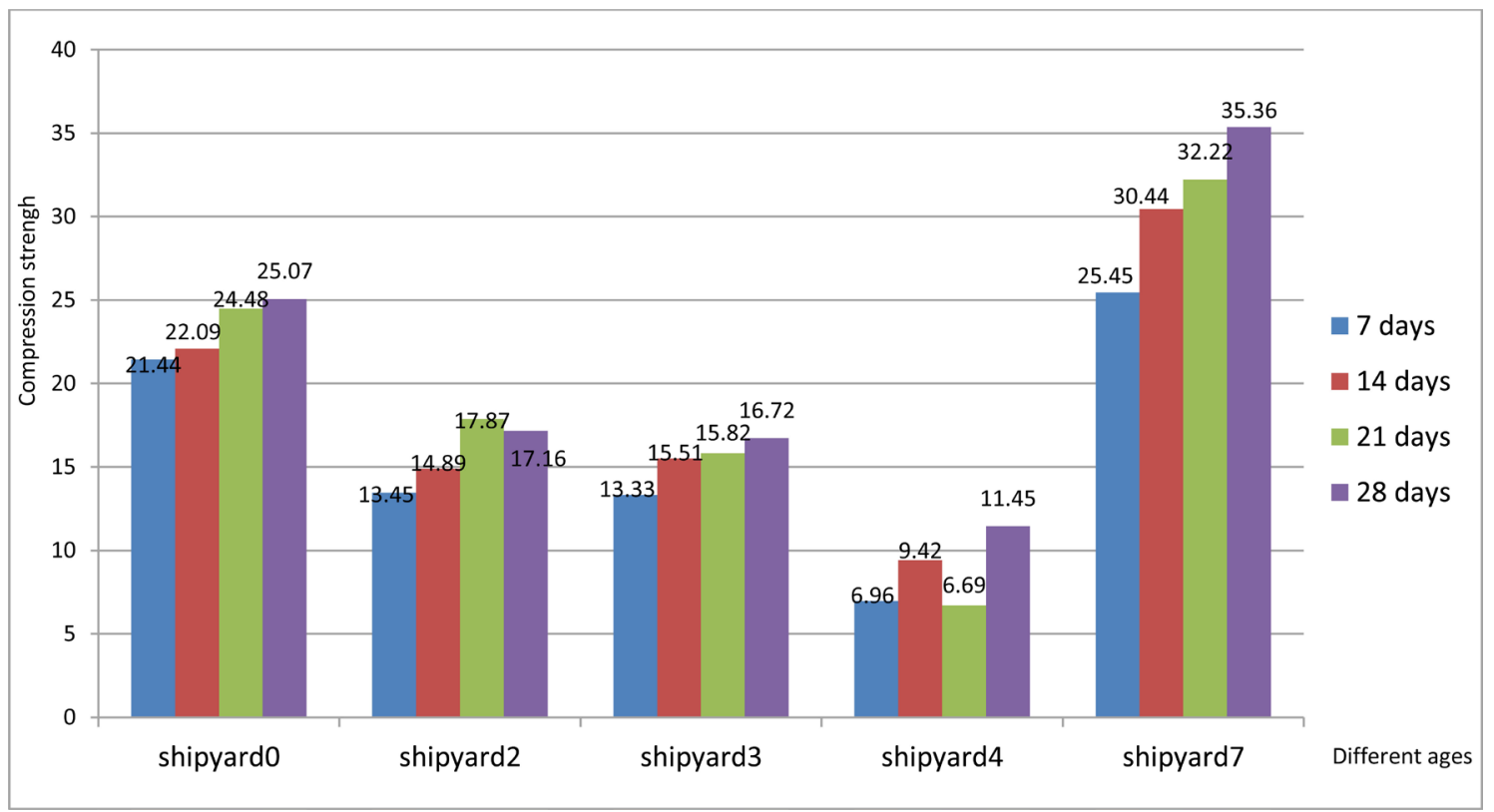

Figure 5. Resistance results of concretes to compression (four measures).

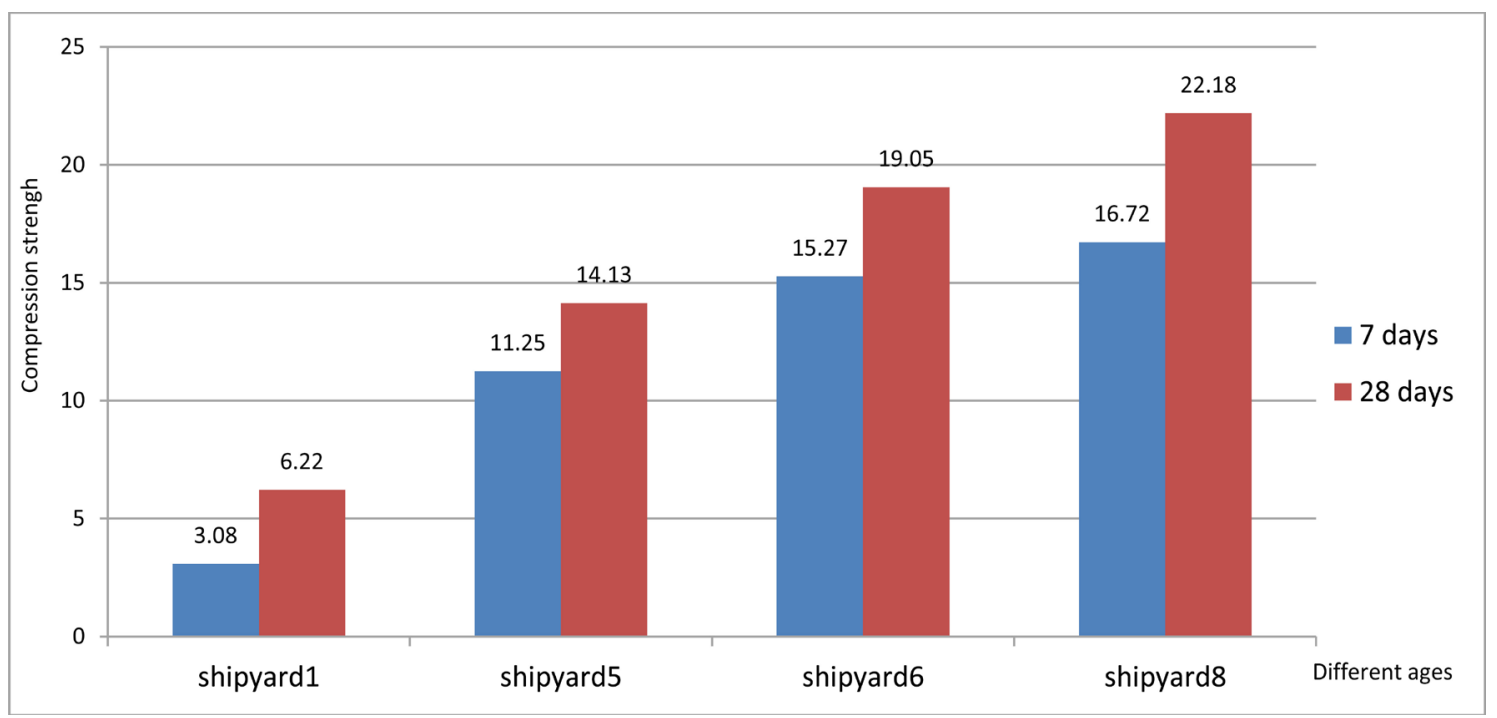

Figure 6. Resistance results of concretes to compression (two measures).

of a concrete of very low quality because the average resistance to compression corresponds to that of a concrete of cleanliness. These concretes are not required for the load-bearing elements in the construction and are far from a dosage of $350 \mathrm{Kg} / \mathrm{m}^{3}$;

- Site 7 is atypical and has an expected average compressive strength of concrete obtained at 28 days of age of $28.29 \mathrm{MPa}$. This concrete is characteristic of a concrete of very good quality because this resistance corresponds to a concrete of normal type whose values vary between $20 \mathrm{MPa}$ and $30 \mathrm{MPa}$. This concrete is usable for the load-bearing elements in the construction.

Overall, these results obtained after analysis have not been conclusive because 
the implementation rules for the formulation of these concretes have not been respected by professionals in the informal and semi-informal sectors of construction. The reasons are diverse and can be summarized by the lack of knowledge of building standards and mastery of appropriate technology.

\section{Results of granulometrical analysis of aggregates}

Here, the granulometrical analysis carried out on three categories of sands of Djiri, of the Congo river and of Mfilou (another career difficult exploitable) showed that these rolled sands were not conclusive. These are very far from normality because they contain too many fine particles (Figure 7). For this, it was necessary to make a physical improvement with crushed sand. Indeed, although it is also rich in fine elements, it better meets the criterion of concrete sand (Figure 8). It seems to be good for improving the performance of other types of sand.

Thus, the results of the mixtures obtained after improvement, namely, Djiri sand plus crushed sand and Congo River sand plus crushed sand, are given in Figure 9.

It is noted that this improvement of the physical characteristics, in particular

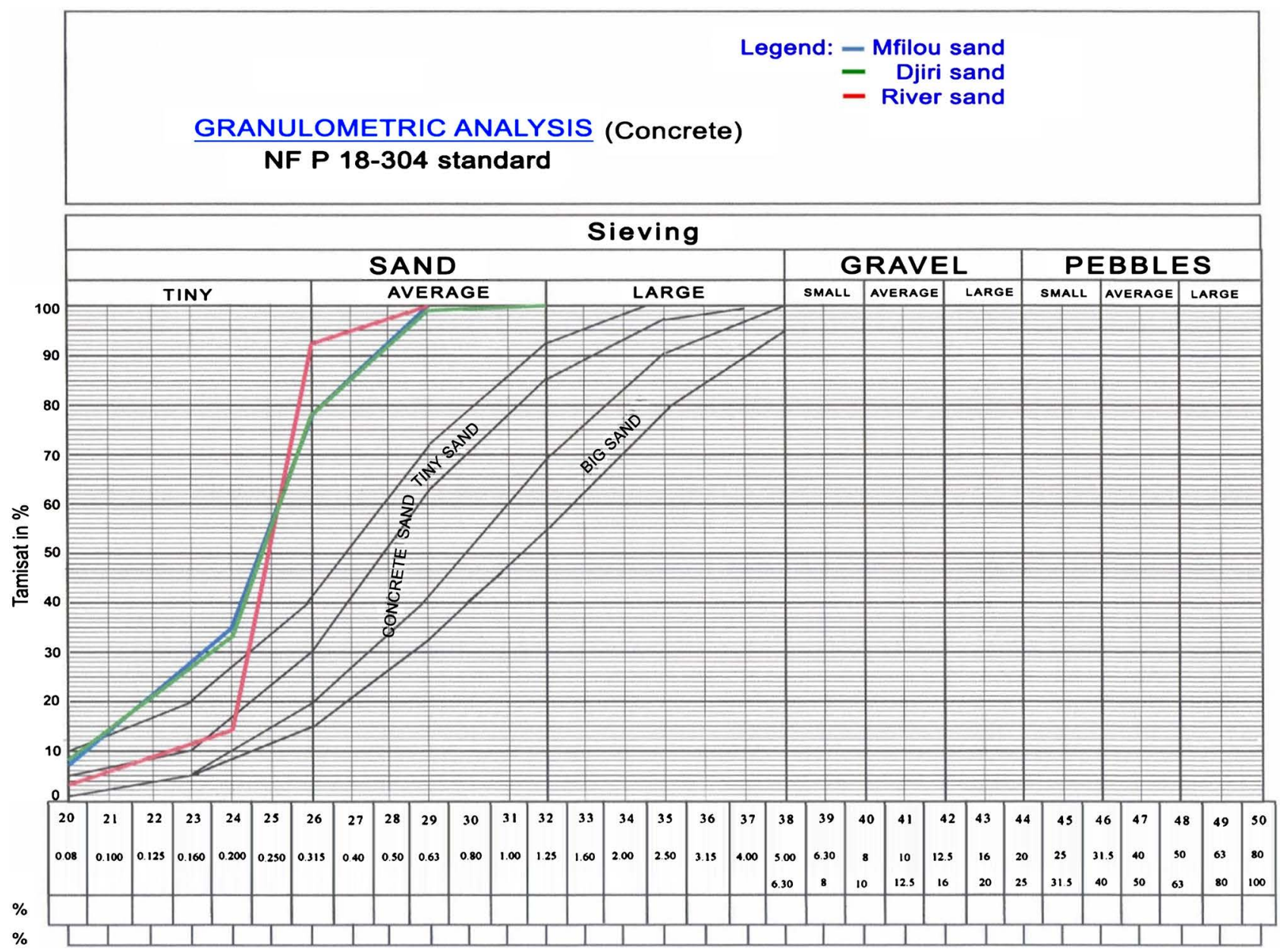

Figure 7. Granulometrical analysis of the sands of Djiri, Congo River and Mfilou. 


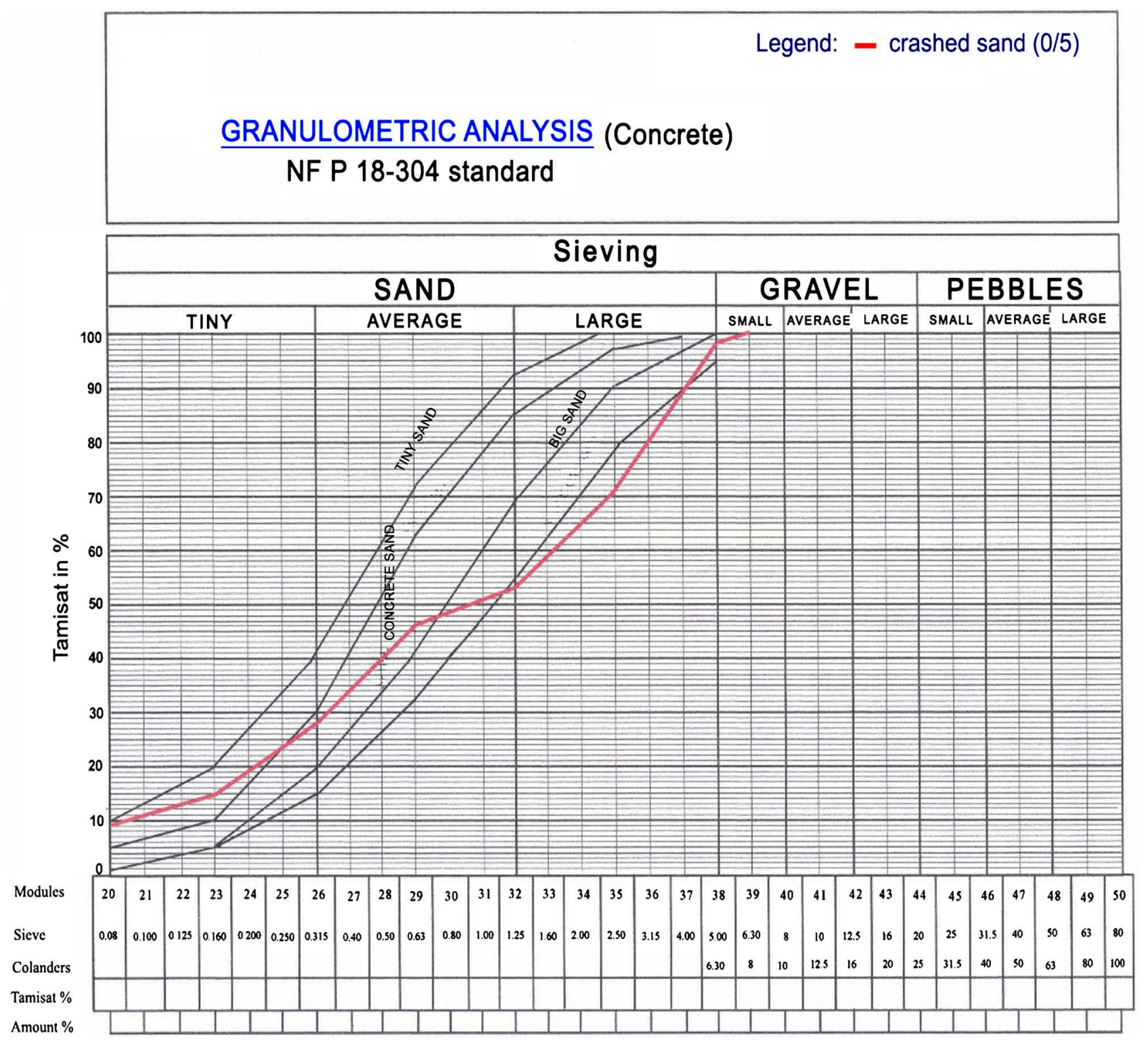

Figure 8. Particle size analysis of crushed sand.

their granulometry, allowed that these approach the normal sand.

The results obtained after crushing the specimens at 7, 14, 21 and 28 days of age are shown in the tables below for each formulation. Six (6) formulation variants of the concretes were examined in the laboratory.

Formulation 1: (Djiri sand 0/0.63 mixed with both classes of gravel (3.15/16 and $12.5 / 25)$ )

The application of the Dreux-Gorisse method for the formulation of concrete dosed at $350 \mathrm{Kg} / \mathrm{m}^{3}$ yielded the results recorded in Table 3 .

The results of simple compressive strengths after crushing cubic specimens are shown in Table 4.

The 28-day-old compressive strength found shows that this concrete is typical of medium grade concrete because it is of normal type. 


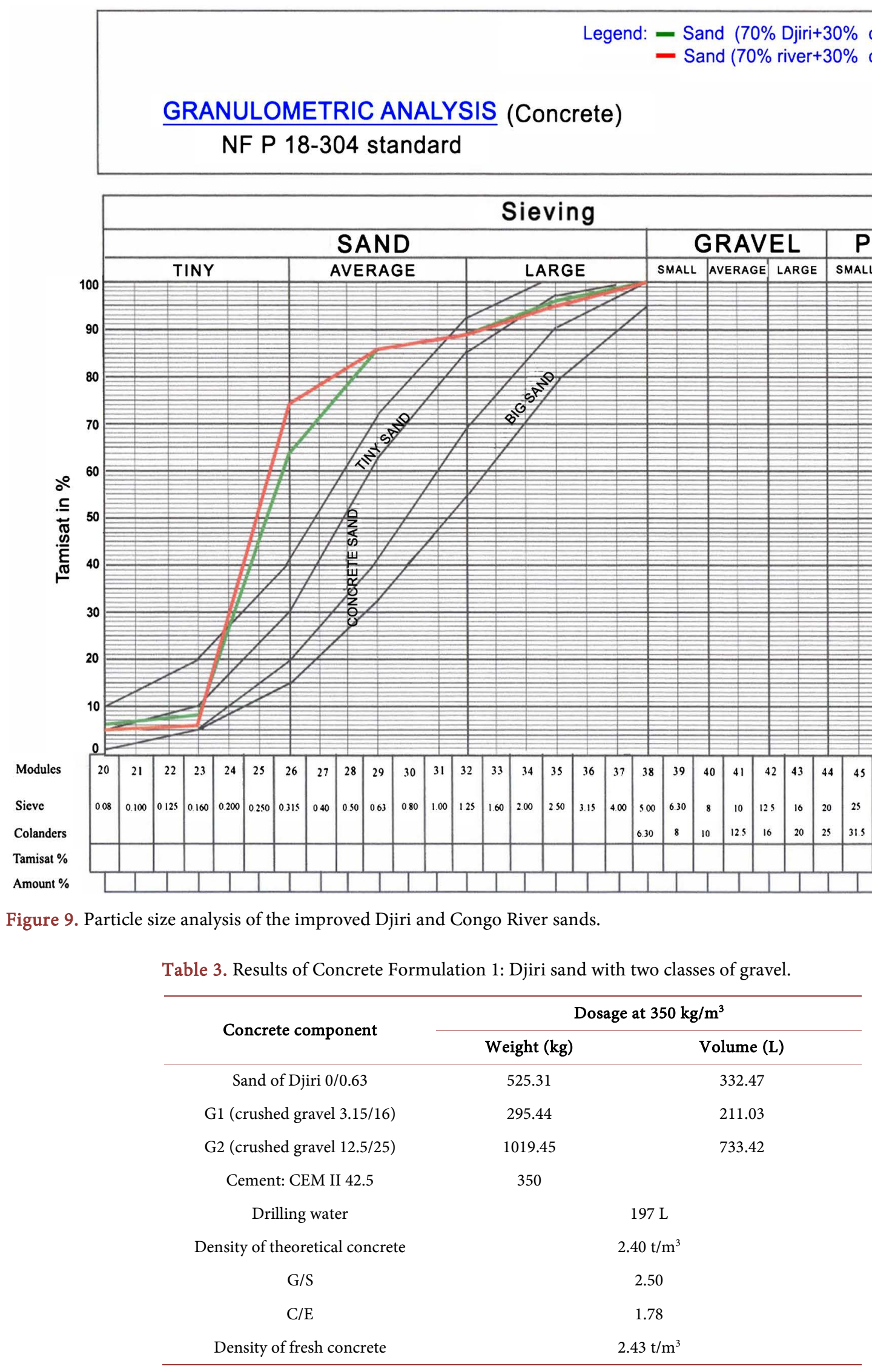


Formulation 2: (Djiri sand 0/0.63 with the mixture of two classes of gravel G1 + G2 (50\% G1 + 50\% G2: (5/25), see Table 2). The results of the composition of the mixture obtained are shown in Table 5 .

The results of simple compressive strengths after crushing cylindrical specimens are shown in Table 6.

Table 4. Characteristic Results of Concrete (Formulation 1).

\begin{tabular}{|c|c|c|c|c|c|c|c|c|}
\hline \multirow{2}{*}{$\begin{array}{l}\text { Concrete } \\
\text { age/days }\end{array}$} & \multirow{2}{*}{$\begin{array}{l}\text { Density } \\
\text { in } t / \mathrm{m}^{3}\end{array}$} & \multirow{2}{*}{ Average } & \multirow{2}{*}{$\begin{array}{c}\text { Résistance } \\
\text { in } \mathrm{MPa}\end{array}$} & \multicolumn{2}{|c|}{ Averages } & \multirow{2}{*}{ Subsidence } & \multirow{2}{*}{ Consistency } & \multirow{2}{*}{ Weather } \\
\hline & & & & Cube & Cylinder & & & \\
\hline \multirow{3}{*}{7 days } & 2.43 & \multirow{3}{*}{2.43} & 24.37 & \multirow{3}{*}{25.06} & \multirow{3}{*}{21.05} & \multirow{9}{*}{$\begin{array}{c}18 \mathrm{~cm} \text { (with } \\
\text { adjuvant) }\end{array}$} & \multirow{9}{*}{ Very soft } & \multirow{9}{*}{ Soft time } \\
\hline & & & & & & & & \\
\hline & 2.42 & & 25.75 & & & & & \\
\hline \multirow{2}{*}{14 days } & 2.44 & \multirow{2}{*}{2.46} & 26.08 & \multirow{2}{*}{27.08} & \multirow{2}{*}{21.66} & & & \\
\hline & 2.47 & & 28.08 & & & & & \\
\hline \multirow[b]{2}{*}{21 days } & 2.43 & \multirow[b]{2}{*}{2.43} & 28.82 & \multirow[b]{2}{*}{27.49} & \multirow[b]{2}{*}{21.99} & & & \\
\hline & 2.43 & & 26.16 & & & & & \\
\hline \multirow[b]{2}{*}{28 days } & 2.44 & \multirow[b]{2}{*}{2.43} & 29.76 & \multirow[b]{2}{*}{28.73} & \multirow[b]{2}{*}{22.98} & & & \\
\hline & 2.42 & & 27.70 & & & & & \\
\hline
\end{tabular}

Table 5. Concrete formulation 2 results (case of Djiri sand with G1 + G2 mixture).

\begin{tabular}{ccc}
\hline \multirow{2}{*}{ Concrete component } & \multicolumn{2}{c}{ Dosage at $350 \mathrm{~kg} / \mathrm{m}^{3}$} \\
\cline { 2 - 3 } Sand of Djiri 0/0.63 & 579.65 & Volume (L) \\
\hline Crushed gravel G1 + G2 (5/25) & 1260.4 & 896.87 \\
Cement: CIMAF CEM II 42.5 & 350 & \\
Drilling water from BCBTP & \multicolumn{2}{c}{$197 \mathrm{~L}$} \\
Density of theoretical concrete & $2.38 \mathrm{t} / \mathrm{m}^{3}$ \\
G/S & 2.17 \\
C/E & \multicolumn{2}{c}{1.78} \\
Density of fresh concrete & $2.39 \mathrm{t} / \mathrm{m}^{3}$ \\
\hline
\end{tabular}

Table 6. Characteristic Result of Concrete (Formulation 2).

\begin{tabular}{|c|c|c|c|c|c|c|c|}
\hline $\begin{array}{l}\text { Concrete } \\
\text { age/days }\end{array}$ & $\begin{array}{l}\text { Density } \\
\text { in } t / m^{3}\end{array}$ & Average & $\begin{array}{l}\text { Résistance } \\
\text { in } \mathrm{MPa}\end{array}$ & Averages & Subsidence & Consistency & Weather \\
\hline 7 days & $\begin{array}{l}2.33 \\
2.29\end{array}$ & 2.31 & $\begin{array}{l}20.00 \\
19.90\end{array}$ & 20.00 & \multirow{4}{*}{$8 \mathrm{~cm}$} & \multirow{4}{*}{ Plastic } & \multirow{4}{*}{$\begin{array}{l}\text { Time } \\
\text { sunny }\end{array}$} \\
\hline 14 days & $\begin{array}{l}2.34 \\
2.36\end{array}$ & 2.35 & $\begin{array}{l}26.27 \\
24.47\end{array}$ & 25.37 & & & \\
\hline 21 days & $\begin{array}{l}2.37 \\
2.33\end{array}$ & 2.35 & $\begin{array}{l}25.32 \\
27.92\end{array}$ & 26.62 & & & \\
\hline 28 days & $\begin{array}{l}2.37 \\
2.35\end{array}$ & 2.36 & $\begin{array}{l}27.78 \\
25.73\end{array}$ & 26.76 & & & \\
\hline
\end{tabular}


The compressive strength at 28 days of age of concrete shows that this concrete is of required quality because it corresponds to a concrete dosed at 350 $\mathrm{Kg} / \mathrm{m}^{3}$.

Formulation 3: (Congo River sand with G1 + G2 gravel). The results of this formulation are presented in Table 7.

The results of simple compressive strengths after crushing cylindrical specimens are shown in Table 8. This resistance obtained at 28 days of age of this concrete shows that this type of concrete is of very good quality.

Formulation 4: (improved Djiri sand with both types of gravel G1 + G2)

The results of the composition of the mixture obtained are shown in Table 9.

The simple compressive strength of this type of concrete is between $20 \mathrm{MPa}$ and $30 \mathrm{MPa}$, so this is a normal concrete type Table 10.

Formulation 5: (improved Congo River sand with both types of G1 and G2 gravel), see Table 11. It reveals that the result of the composition of mixture are shown in Table 11.

Table 7. Results Formulation 3 (River and G1 + G2).

\begin{tabular}{ccc}
\hline \multirow{2}{*}{ Concrete component } & \multicolumn{2}{c}{ Dosage at $350 \mathrm{~kg} / \mathrm{m}^{3}$} \\
\cline { 2 - 3 } Congo River sand 0/0.63 & Weight (kg) & Volume (L) \\
Crushed gravel G1+G2 5/25 & 1278.95 & 383.48 \\
Cement: CIMAF CEM II 42.5 & 350 & 907.10 \\
Drilling water from BCBTP & \multicolumn{2}{c}{$197 \mathrm{~L}$} \\
Density of theoretical concrete & $2.38 \mathrm{t} / \mathrm{m}^{3}$ \\
G/S & 2.27 \\
C/E & \multicolumn{2}{c}{1.78} \\
Density of fresh concrete & $2.39 \mathrm{t} / \mathrm{m}^{3}$ \\
\hline
\end{tabular}

Table 8. Characteristic Results of Concrete (Formulation 3).

\begin{tabular}{|c|c|c|c|c|c|c|c|}
\hline $\begin{array}{c}\text { Concreteage/ } \\
\text { days }\end{array}$ & $\begin{array}{l}\text { Density } \\
\text { int } / \mathrm{m}^{3}\end{array}$ & Average & $\begin{array}{l}\text { Resistance } \\
\text { in } \mathrm{MPa}\end{array}$ & Averages & Subsidence & Consistency & Weather \\
\hline 7 days & $\begin{array}{l}2.27 \\
2.29\end{array}$ & 2.28 & $\begin{array}{l}22.99 \\
22.39\end{array}$ & 22.69 & & & \\
\hline 14 days & $\begin{array}{l}2.27 \\
2.29\end{array}$ & 2.28 & $\begin{array}{l}25.62 \\
25.87\end{array}$ & 25.75 & & & \\
\hline 21 days & $\begin{array}{l}2.31 \\
2.29\end{array}$ & 2.30 & $\begin{array}{l}28.30 \\
26.32\end{array}$ & 27.31 & $6 \mathrm{~cm}$ & Plastic & Mild time \\
\hline 28 days & $\begin{array}{l}2.36 \\
2.33\end{array}$ & 2.35 & $\begin{array}{l}27.46 \\
27.36\end{array}$ & 27.41 & & & \\
\hline
\end{tabular}


Table 9. Formulation Results 4 (enhanced by sand and both types of gravel).

\begin{tabular}{ccc}
\hline & \multicolumn{2}{c}{ Dosage at $350 \mathrm{~kg} / \mathrm{m}^{3}$} \\
\cline { 2 - 3 } Concrete component & Weight (kg) & Volume (L) \\
\hline Djiri sand improved 0/2.50 & 581.90 & 363.69 \\
Crushed gravel 3.15/16 & 240.05 & 171.46 \\
Crushed gravel 12.5/25 & 1019.45 & 733.42 \\
Cement: CIMAF CEM II 42.5 & 350 & \\
Drilling water from BCBTP & $197 \mathrm{~L}$ \\
Density of theoretical concrete & $2.39 \mathrm{t} / \mathrm{m}^{3}$ \\
G/S & 2.16 \\
C/E & \multicolumn{2}{c}{1.78} \\
Density of fresh concrete & $2.39 \mathrm{t} / \mathrm{m}^{3}$ \\
\hline
\end{tabular}

Table 10. Characteristic Results of Concrete (Formulation 4).

\begin{tabular}{cccccccc}
\hline $\begin{array}{c}\text { Concrete } \\
\text { age/days }\end{array}$ & $\begin{array}{c}\text { Density } \\
\text { in } \mathrm{t} / \mathrm{m}^{3}\end{array}$ & Average & $\begin{array}{c}\text { Résistance } \\
\text { in } \mathrm{MPa}\end{array}$ & Average & Subsidence & Consistency Weather \\
\hline 7 days & 2.36 & 2.36 & 20.25 & & & & \\
& 2.35 & & 20.50 & 20.38 & & & \\
& 2.30 & & 24.30 & & & Plastic & Mild \\
14 days & 2.31 & 2.31 & 26.34 & 25.32 & & \\
& 2.34 & & 26.35 & & & \\
21 days & 2.32 & 2.33 & 24.38 & & & \\
& 2.39 & & 25.37 & & & \\
28 days & 2.39 & 2.39 & 25.57 & & & & \\
& & & 25.55 & & & \\
\hline
\end{tabular}

Table 11. Results formulation 5 (improved river the two gravels G1 and G2).

\begin{tabular}{|c|c|c|}
\hline \multirow{2}{*}{ Concrete component } & \multicolumn{2}{|c|}{ Dosage at $350 \mathrm{~kg} / \mathrm{m}^{3}$} \\
\hline & Weight $(\mathrm{kg})$ & Volume (L) \\
\hline River sand improved 0/2.50 & 602.40 & 398.94 \\
\hline G1 (Crushed gravel 3.15/16) & 221.58 & 158.27 \\
\hline G2 (Crushed gravel 12.5/25) & 1019.45 & 733.42 \\
\hline Cement: CIMAF CEM II 42.5 & 350 & \\
\hline Drilling water from $\mathrm{BCBTP}$ & \multicolumn{2}{|c|}{$197 \mathrm{~L}$} \\
\hline Density of theoretical concrete & \multicolumn{2}{|c|}{$2.39 \mathrm{t} / \mathrm{m}^{3}$} \\
\hline $\mathrm{G} / \mathrm{S}$ & \multicolumn{2}{|c|}{2.06} \\
\hline $\mathrm{C} / \mathrm{E}$ & \multicolumn{2}{|c|}{1.78} \\
\hline Density of fresh concrete & \multicolumn{2}{|c|}{$2.39 \mathrm{t} / \mathrm{m}^{3}$} \\
\hline
\end{tabular}


The results of simple compressive strengths after crushing cylindrical specimens are shown in Table 12.

The dosage of this concrete is $350 \mathrm{Kg} / \mathrm{m}^{3}$ and corresponds to a normal type of concrete that can be used in the load-bearing elements. Applying the age coefficients to evaluate the resistance at 7 days from the resistance found at 7, 14, 21 or 28 days, we obtain the results in Table 12.

Formulation 6 (crushed sand with both classes of gravel). The formulation results are presented in Table 13.

The results of the simple compressive strengths after crushing cylindrical specimens are shown in Table 14. The compressive strength at 28 days of age of this concrete is characteristic of medium quality concrete.

Applying the age coefficients to evaluate the resistance at 7 days from the resistance found at 7, 14, 21 or 28 days, we obtain the results in Table 14 .

The results obtained from the six (6) formulations produced for a dosage of $350 \mathrm{Kg} / \mathrm{m}^{3}$ can be selected for the informal and semi-informal construction sectors, since the compressive strength at 28 days of age of concrete is between 20 and $30 \mathrm{MPa}$ (Figure 10).

Table 12. Results of Concrete Formulation (Formulation 5).

\begin{tabular}{|c|c|c|c|c|c|c|c|}
\hline $\begin{array}{l}\text { Concrete } \\
\text { age/days }\end{array}$ & $\begin{array}{l}\text { Density } \\
\text { in } t / \mathrm{m}^{3}\end{array}$ & Average & $\begin{array}{c}\text { Resistance } \\
\text { in } \mathrm{MPa}\end{array}$ & Average & Subsidence & Consistency & Weather \\
\hline 7 days & $\begin{array}{l}2.30 \\
2.28\end{array}$ & 2.29 & $\begin{array}{l}20.20 \\
20.00\end{array}$ & 20.10 & & & \\
\hline 14 days & $\begin{array}{l}2.32 \\
2.33\end{array}$ & 2.33 & $\begin{array}{l}25.92 \\
23.93\end{array}$ & 24.93 & $x_{0}$ & Dh & S C. \\
\hline 21 days & $\begin{array}{l}2.36 \\
2.33\end{array}$ & 2.35 & $\begin{array}{l}23.65 \\
26.89\end{array}$ & 25.27 & & & \\
\hline 28 days & $\begin{array}{l}2.35 \\
2.35\end{array}$ & 2.35 & $\begin{array}{l}25.87 \\
25.72\end{array}$ & 25.80 & & & \\
\hline
\end{tabular}

Table 13. Results Formulation 6 (crushed 0/5 and both types of gravel).

\begin{tabular}{|c|c|c|}
\hline \multirow{2}{*}{ Concrete component } & \multicolumn{2}{|c|}{ Dosage at $350 \mathrm{~kg} / \mathrm{m}^{3}$} \\
\hline & Weight (kg) & Volume (L) \\
\hline River sand improved $0 / 2.50$ & 630.94 & 423.45 \\
\hline G1 (Crushed gravel 3.15/16) & 197.33 & 140.95 \\
\hline G2 (Crushed gravel 12.5/25) & 936.39 & 673.66 \\
\hline Cement: CIMAF CEM II 42.5 & 350 & \\
\hline Drilling water from BCBTP & \multicolumn{2}{|c|}{$197 \mathrm{~L}$} \\
\hline Density of theoretical concrete & \multicolumn{2}{|c|}{2.31} \\
\hline $\mathrm{G} / \mathrm{S}$ & \multicolumn{2}{|c|}{1.80} \\
\hline $\mathrm{C} / \mathrm{E}$ & \multicolumn{2}{|c|}{1.78} \\
\hline Density of fresh concrete & \multicolumn{2}{|c|}{2.32} \\
\hline
\end{tabular}


Table 14. Characteristic Results of Concrete (Formulation 6).

\begin{tabular}{|c|c|c|c|c|c|c|c|}
\hline $\begin{array}{l}\text { Concrete } \\
\text { age/days }\end{array}$ & $\begin{array}{l}\text { Density } \\
\text { in } t / \mathrm{m}^{3}\end{array}$ & Average & $\begin{array}{c}\text { Resistance } \\
\text { in } \mathrm{MPa}\end{array}$ & Average & Subsidence & Consistency & Weather \\
\hline 7 days & $\begin{array}{l}2.23 \\
2.27\end{array}$ & 2.25 & $\begin{array}{l}14.33 \\
14.43\end{array}$ & 14.38 & \multirow{4}{*}{$7 \mathrm{~cm}$} & \multirow{4}{*}{ Plastic } & \multirow{4}{*}{$\begin{array}{l}\text { Sunny } \\
\text { time }\end{array}$} \\
\hline 14 days & $\begin{array}{l}2.32 \\
2.35\end{array}$ & 2.34 & $\begin{array}{l}17.48 \\
19.54\end{array}$ & 18.51 & & & \\
\hline 21 days & $\begin{array}{l}2.30 \\
2.32\end{array}$ & 2.31 & $\begin{array}{l}24.06 \\
21.82\end{array}$ & 22.94 & & & \\
\hline 28 days & $\begin{array}{l}2.33 \\
2.32\end{array}$ & 2.33 & $\begin{array}{l}24.80 \\
21.56\end{array}$ & 23.18 & & & \\
\hline
\end{tabular}

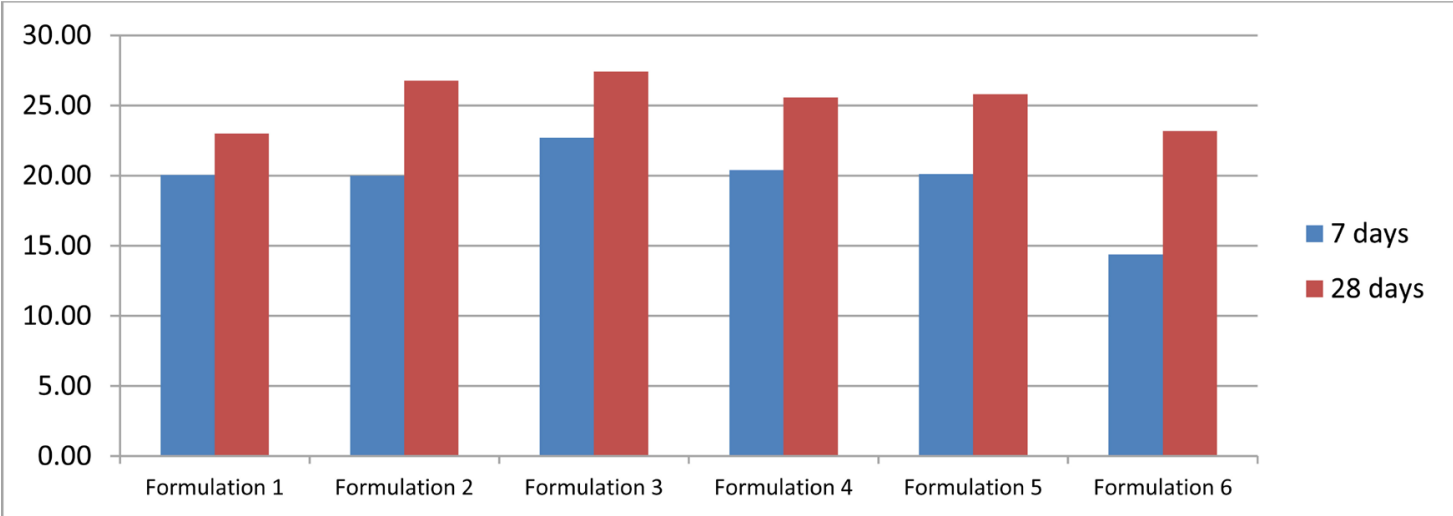

Figure 10. Table of the results of the six concrete formulations carried out.

Here, we also note that for the improved sands, the correction is done by mixing the reference sand with the crushed sand which contains fine particles that stem from the sandstone of the Inkissi.

Indeed, the will often contains clay particles. This justifies the difference between the various formulations.

\section{Statistical analysis}

To verify the level of reliability of the compressive strengths for the proposed formulations, we made an objective observation of the results obtained in the laboratory. We find that there is a discrepancy between the different formulations.

Indeed, given the results in the table below, it appears that the means (statistics) of each formulation are different test (Table 15).

Thanks to the SPSS2 software, we were able to perform the Least Meaning Difference Test (LSD).

By applying the multiple mean comparisons test (Table 16) and taking into account the significance level of $10 \%$, two groups of formulation are observed. The first groups formulations 1 and 6; while the second contains the rest of the formulations (2, 3, 4 and 5). 
Table 15. Distribution of the average resistance by type of formulation according to the age of the concrete.

\begin{tabular}{cccccccc}
\hline Jours & Formulation 1 & Formulation 2 & Formulation 3 & Formulation 4 & Formulation 5 & Formulation 6 & Total \\
\hline 7 Jours & 20.05 & 20.00 & 22.69 & 20.38 & 20.10 & 14.38 & 19.60 \\
14 Jours & 21.08 & 25.37 & 25.75 & 25.32 & 24.93 & 18.51 & 24.49 \\
21 Jours & 22.49 & 26.62 & 27.31 & 25.37 & 25.27 & 22.94 & 25.83 \\
28 Jours & 22.98 & 26.76 & 27.41 & 25.55 & 25.80 & 23.18 & 25.28 \\
Total & 21.65 & 24.69 & 25.79 & 24.15 & 24.02 & 19.75 & 23.80 \\
\hline
\end{tabular}

Table 16. Test of multiple comparisons (LSD) of averages of different formulations.

\begin{tabular}{|c|c|c|c|c|}
\hline (I) Formulation & (J) Formulation & Difference of averages (I-J) & Standard error & $P$-value \\
\hline \multirow{5}{*}{ Formulation 1} & Formulation 2 & $-3.0375^{\star}$ & 1.37590 & 0.033 \\
\hline & Formulation 3 & $-4.1400^{\star}$ & 1.37590 & 0.004 \\
\hline & Formulation 4 & $-2.5025^{\star}$ & 1.37590 & 0.076 \\
\hline & Formulation 5 & $-2.3738^{*}$ & 1.37590 & 0.092 \\
\hline & Formulation 6 & 1.8963 & 1.37590 & 0.175 \\
\hline \multirow{5}{*}{ Formulation 2} & Formulation 1 & $3.0375^{*}$ & 1.37590 & 0.033 \\
\hline & Formulation 3 & -1.1025 & 1.37590 & 0.427 \\
\hline & Formulation 4 & 0.5350 & 1.37590 & 0.699 \\
\hline & Formulation 5 & 0.6638 & 1.37590 & 0.632 \\
\hline & Formulation 6 & $4.9338^{*}$ & 1.37590 & 0.001 \\
\hline \multirow{5}{*}{ Formulation 3} & Formulation 1 & $4.1400^{*}$ & 1.37590 & 0.004 \\
\hline & Formulation 2 & 1.1025 & 1.37590 & 0.427 \\
\hline & Formulation 4 & 1.6375 & 1.37590 & 0.241 \\
\hline & Formulation 5 & 1.7663 & 1.37590 & 0.206 \\
\hline & Formulation 6 & $6.0363^{*}$ & 1.37590 & 0.000 \\
\hline \multirow{5}{*}{ Formulation 4} & Formulation 1 & $2.5025^{\star}$ & 1.37590 & 0.076 \\
\hline & Formulation 2 & -.5350 & 1.37590 & 0.699 \\
\hline & Formulation 3 & -1.6375 & 1.37590 & 0.241 \\
\hline & Formulation 5 & 0.1288 & 1.37590 & 0.926 \\
\hline & Formulation 6 & $4.3988^{*}$ & 1.37590 & 0.003 \\
\hline \multirow{5}{*}{ Formulation 5} & Formulation 1 & $2.3738^{*}$ & 1.37590 & 0.092 \\
\hline & Formulation 2 & -0.6638 & 1.37590 & 0.632 \\
\hline & Formulation 3 & -1.7663 & 1.37590 & 0.206 \\
\hline & Formulation 4 & -0.1288 & 1.37590 & 0.926 \\
\hline & Formulation 6 & $4.2700^{\star}$ & 1.37590 & 0.003 \\
\hline \multirow{5}{*}{ Formulation 6} & Formulation 1 & -1.8963 & 1.37590 & 0.175 \\
\hline & Formulation 2 & $-4.9338^{\star}$ & 1.37590 & 0.001 \\
\hline & Formulation 3 & $-6.0363^{\star}$ & 1.37590 & 0.000 \\
\hline & Formulation 4 & $-4.3988^{\star}$ & 1.37590 & 0.003 \\
\hline & Formulation 5 & $-4.2700^{*}$ & 1.37590 & 0.003 \\
\hline
\end{tabular}


In order to make the information mentioned above robust, we preferred to refine this study by a factorial analysis. The goal is to know the formulations that have statistically the same resistances and those that oppose. For this purpose, we opted for principal component analysis by introducing two continuous variables into active (strength and density) and two nominal variables into illustrative (type of formulation and age of concrete), Figure 11.

For this we used the software Spas. 5.

The results in Figure 11 reveal four groups of formulation. In this figure, the evolution of compressive strength as a function of age is from right to left.

This factorial analysis in principal component, on the first two variables (resistance and density) and the two others (type of formulation and age of the concrete), reveals the composition of 4 distinct groups:

- Group 1, contains formulation 3 which is much more resistant than other formulations, regardless of the age of the concrete. This is the most important resistance group;

- Formulations group 2, formulations 2, 4 and 5. It can be considered as the group of formulations whose impact resistance is acceptable.

- Group 3 (formulation 1) has low resistance but also contains the highest density;

- Group 4 (formulation 6) is low in strength and high in density.

It can thus be noted that in Group 2, the compressive strengths of concrete at different ages are fairly close and acceptable overall, while their densities are relatively low. Group 1 is atypical from the point of view of its resistance. Groups 3 and 4 have concrete formulations with very close minimum values of

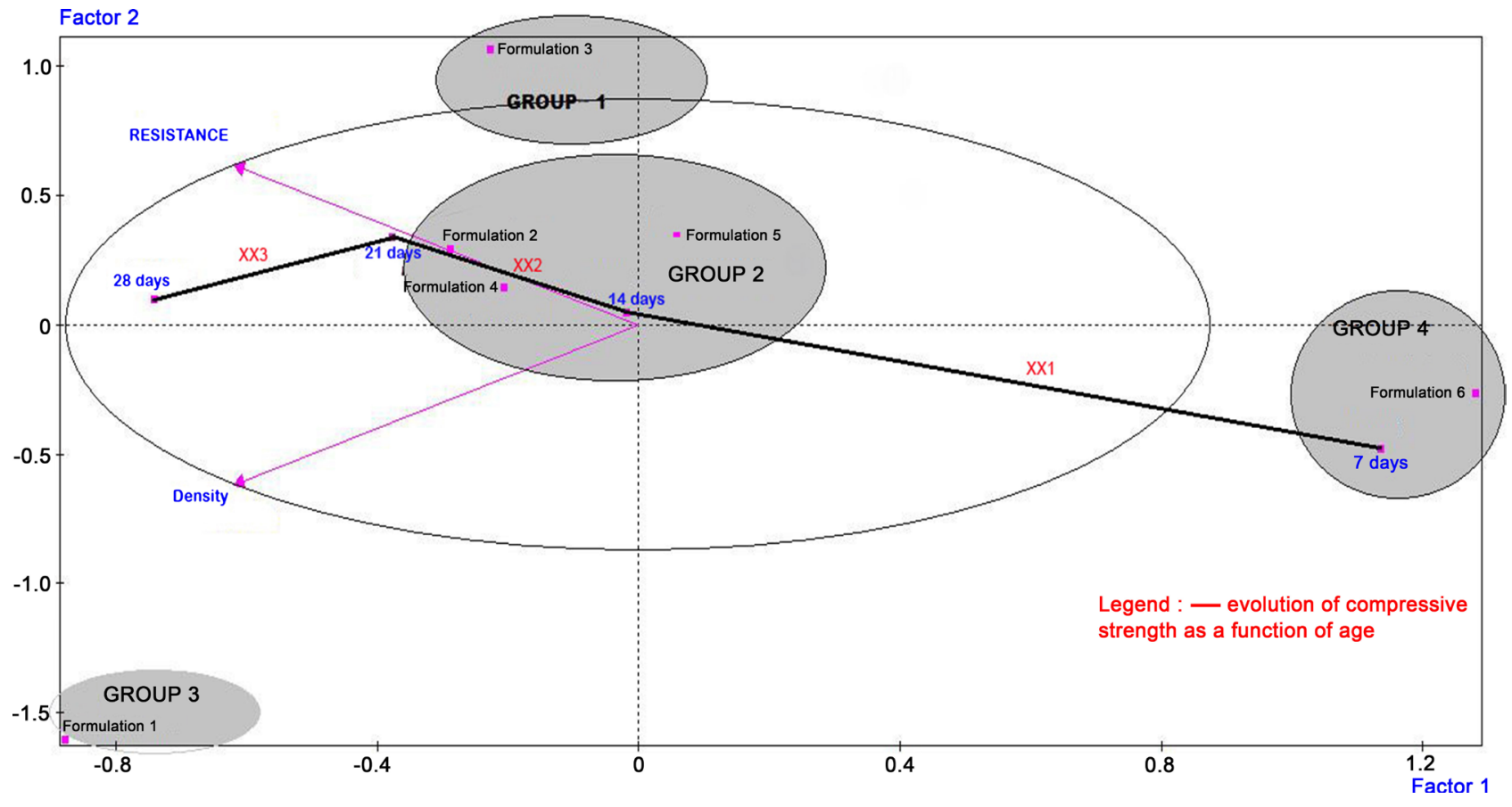

Figure 11. Main plan of the factor analysis. 
22.98 $\mathrm{MPa}$ and 23.18 $\mathrm{MPa}$, respectively. The XX1, XX2, XX3 lines translate the evolution of the compressive strengths for different formulations over the ages. Indeed, at 7 days, the formulation 6 (group 4) has the lowest value. At 14 and 21 days of age, there is a clear evolution of resistance but very remarkable for group 2. And, at 28 days of age, we find formulation 3 (group 1) with the greatest value while the lower is at the level of formulation 1 of group 3.

In view of the above, we can say that the best formulation is that which consists of Congo River sand, with gravel G1 + G2 (formulation 3). In addition, low strength formulations are those consisting of aggregates (Djiri sand with gravel G1 and G2) for formulation 1, and then (sand crushed with gravel G1 + G2) for formulation 6 .

\section{Discussion}

The results discussed mainly concern the formulation of concretes. Several studies have been carried out as part of the determination of concrete compositions and their technical specifications. Many have been published [3] [6] [17] [18] [19] [20] and [21].

From the point of view of the methodological approach, Turcy and Loukili (2003), who conducted studies on the formulation of self-placing concretes (BAP), point out that the scope of the formulator's possibilities can be widened by trying to apply other methods, highlighting the minimization of the binder paste or the optimization of the granular skeleton. These studies nevertheless reveal that the compressive strengths of concretes are at least $40 \%$ higher than those of ordinary concretes (Dreux-Gorisse), despite a similar E/C ratio. This highlights the role of pulp volume and limestone filler on the compactness of the solid skeleton of self-placing concretes (BAP) [22].

It thus appears that the strengths of ordinary concretes can be further improved if one really studies the influence of the granular class on the cementitious material [23] [24] and [25].

However, Drissi et al. (2005), in their studies on the influence of concrete composition parameters on its compressive strength, also point out all the remarkable progress on concretes, from the point of view of the rheology that the mechanical behavior are due to the thorough knowledge of the physico-chemical properties of the constituents (sand, gravel, cements). This technical argumentation is also supported by Larrard et al. (2010), as well as Makhaly et al. (2014).

Similarly, the 28-day compressive strength for ordinary concrete decreases by $17 \%$ by increasing the $\mathrm{E} / \mathrm{C}$ ratio from 0.5 to 0.55 . This could also be explained to a certain extent by a lack of hydrated calcium silicate (C-S-H) formation that is most involved in the development of resistance [18].

Berredjen et al. (2015) used the Dreux-Gorisse formulation method for the manufacture of concretes needed to study the durability indicators of recycled aggregates based on natural rolled aggregates.

This study also reveals that the mechanical strength of a concrete is funda- 
mentally linked to the mechanical performance of the aggregates since at 28 days, concrete composed of $75 \%$ natural aggregates and $25 \%$ recycled aggregates have a better resistance (in compression and traction) [5] [21] [26] and [27].

In addition to this comparison made on the different formulations of concretes where the dependence of the physico-mechanical performances of concretes in relation to the granular class and the $\mathrm{C} / \mathrm{E}$ ratio has been demonstrated, the different formulations proposed for the informal and semi-presented in this study comply with the standard.

Thus, it remains to re-evaluate the activity of the influence of the granular class on the cement matrix to further improve the performance of these concretes.

\section{Conclusions}

This study was an attempt to seek solution for efficient concrete formulation for $\mathrm{fC}_{28}$ of 20 and $30 \mathrm{MPa}$ in the informal and semi-informal construction sectors. It was carried out in the laboratory using the Dreux-Gorisse method on construction materials taken from the quarries around Brazzaville. Also, a survey was conducted in the same frame. This involved taking fresh concrete from various construction sites in Brazzaville.

The results obtained after crushing samples of concrete collected fresh in situ and tested in the laboratory, showed on eight (8), five (5) samples have the characteristics of non-conforming concrete at a dosage of $350 \mathrm{Kg} / \mathrm{m}^{3}$, one (1) only site (site 7) has the characteristics of a concrete of quality or normal type; site 8 shows characteristics of medium quality concrete. This imbalance is explained by the lack of control of the appropriate technology.

As regards the formulation of concretes, the exploitation of the Dreux-Gorris method requires an improvement in the physical properties of sands which contain too fine elements.

Thus, the size of fine sand particles (Djiri and Congo River) has been improved with crushed sand to bring them closer to normal sand (NFP15-403), the case of formulations 4 and 5 .

Of the six (06) formulations, the 28-day-old characteristic compressive strength (fc28) results ranged from 22.98 to $27.4 \mathrm{MPa}$.

These values are in the range of 20 to $30 \mathrm{MPa}$, which is considered as a benchmark in the technical specifications of common civil engineering structures in the informal and semi-formal construction sectors.

In sum, these types of formulations can be retained by these sectors of the construction for the manufacture of concrete of quality required for a good durability of the works.

\section{Acknowledgements}

This work was done in the framework of a collaboration between the National School of Polytechnic (ENSP), University Marien Ngouabi and the Office of 
Building Control and Public Works (BCBTP).

We are grateful to the officials and agents who contributed to the development of this work.

\section{Conflicts of Interest}

The authors declare no conflicts of interest regarding the publication of this paper.

\section{References}

[1] Pettang, C., Vermande, P. and Zimmermann, M. (1999) Impact du secteur informel dans la production de l'habitat au Cameroun, $21 \mathrm{p}$.

[2] Planetscope (2018) Statistiques mondiales en temps réel. En ligne sur. https://www.planetscope.com/matiere.../1374-production-mondiale-debeton.htlm

[3] Turcy, P. and Loukili, A. (2003) Différentes approches pour la formulation des bétons autoplaçants. Influence sur les caractéristiques géologiques et mécaniques. http://hal.archives-ouerts.fr/hal-01006744\%20document

[4] Mechling J.M. (2000) Formulation de bétons courants avec le grès du Luxembourg et les Kieselguhrs usagés des brasseries. Thèse de doctorat, université Henri Poincaré, Nancy I, option: Géologie appliquée au génie civil, 307 p.

[5] El-Amine Boukly Hacene, S.M., Ghomari, F. and Khelidj, A. (2009) Compressive Strengths of Concrete Formulated with Algerian Local Materials. Jordan Journal of Civil Engineering, 3, 103-117.

[6] Jankovic, K., Nikolic, D., Bojovic, D., Loncan, L. and Romakou, Z. (2011) The Estimation of Compressive Strength of Normal and Recycled Aggregate Concrete. Facta Universitatis. Architecture and Civil Engineering, 9, 419-431.

[7] Tchissambou, P. (2015) Formulation des bétons courants à fC28 égale à 20 et 25 $\mathrm{MPa}$-Analyse mécanique comparé. Mémoire d'ingénieur de conception Université Marien Ngouabi École Nationale Supérieure Polytechnique à Brazzaville, Congo, $104 \mathrm{p}$.

[8] Castaldo, P., Gino, D., Bertagnoli, G. and Mancini, G. (2018) Partial Safety Factor for Resistance Model Uncertainties in 2D Non-Linear Finite Element Analysis of Reinforced Concrete Structures. Engineering Structures, 176, 746-762. https://doi.org/10.1016/j.engstruct.2018.09.041

[9] Castaldo, P., Gino, D., Carbone, V.I. and Mancini, G. (2018) Framework for Definition of Design Formulations from Empirical and Semi-Empirical Resistance Models. Structural Concrete, 19, 980-987. https://doi.org/10.1002/suco.201800083

[10] Castaldo, P., Palazzo, B. and Mariniello, A. (2017) Effects of the Axial Force Eccentricity on the Time-Variant Structural Reliability of Aging R.C. Cross-Sections Subjected to Chloride-Induced Corrosion. Engineering Structures, 130, 261-274. https://doi.org/10.1016/j.engstruct.2016.10.053

[11] El Amri, N., Sabbar, M., Chakir, H. and Mangoub, G. (2012) Détermination expérimentale de coefficient de diffusion des ions chlorures dans le béton armé. Faculté des Sciences techniques de Settat, Faculté des Sciences Ben M’sik, Casablanca, Maroc.

[12] Affes, R. (2012) Relation microstructure-fissuration perméabilité dans les milieux granulaires cimentés. Thèse de doctorat en Sciences et techniques de Languedoc: 
Spécialité mécanique et génie civil: université Montpellier II, 143 p.

[13] Desmettre, C. (2011) Contribution à l'étude de la perméabilité du béton armé sous sollicitations statiques et cycliques. Thèse de doctorat $(\mathrm{PhD})$, Département des génies civils, géologique et des mines. École polytechnique de Montréal, Canada.

[14] Dreux, G. (1983) Nouveau guide du béton, Collection UTI-ITBTP, Quatrième édition (Revue et Corrigée), EYROLLES Ed., Paris, 309 p.

[15] Dreux, G. and Festa, J. (1998) Nouveau guide du béton et de ses constituants, Huitième édition, Troisième tirage 2007, EYROLLES Ed., Paris.

[16] Makela, J.B. (2016) Approche de solution pour une formulation efficiente de béton pour fc28 comprise entre 20 et $25 \mathrm{Mpa}$ dans les secteurs informels et semi-informels de la construction. Cas de la ville de Brazzaville. Mémoire d'ingénieur, École Nationale Supérieure Polytechnique/université Marien Ngouabi, Brazzaville Congo.

[17] Drissi, M., Mezghiche, B. and Khouadia, M.L.K. (2015) Influence des paramètres de composition du béton sur sa résistance de compression. Courrier du savoir No. 20, Université Mohamed Khider-Briska, Algérie, 73-78.

[18] Boukli Hacene, S.M.A., Ghouari, F., Schoefs, F. and Khelidja, A. (2003) Étude expérimentale et statistique de l'influence de l'affaissement et de l'ai à la compression des bétons. Lebanese Science Journal, 10.

[19] Makhaly, B., Babacar, D. and Oumar, K. (2015) Étude comparative des bétons hydrauliques et des bétons bitumeux à base de granulats de basaltes de Diack et de quartzites de Bakel. Revue du CAMES-Sciences appliquées de l'ingénieur.

[20] De Larrard, F. and Belloc, A. (2010) L'Influence des granulats sur la résistance à la compression des bétons. Bulletin des laboratoires des ponts et chaussées No. 219. http://trid.org/view/961073 du 12/01/2018

[21] Jorge de Brito, R.K. and Raposeiro da Silva, P. (2018) Can We Truly Predict the Compressive Strength of Concrete without Knowing the Properties of Aggregate? Applied Sciences, 8, 1095.

[22] Metwally Abdallah, A.E. (2014) Compressive Strength Prediction of Portland Cement Concrete with Age Using a New Model. HBRC Journal, 10, 145-155. https://doi.org/10.1016/j.hbrcj.2013.09.005

[23] Ke, X., Ortola, S., Beaucour, A.L, Cabrillac, R. and Dumontet, H. (2006) Influence of Aggregates on Mechanical Behavior of Lightweight Aggregate Concrete: Experimental Characterization and Modelling. First Euro Mediterranean in Advances on Geomaterials and Structures, Hammamet, 3-5 May 2006.

[24] Bouhamou, N., Belas, N., Mesbah, H., Mebrouki, A. and Yahia, A (2008) Influence des paramètres de composition sur le comportement du béton autoplaçants à l'état frais. Faculté des sciences de l'ingénieur, Université Abdelhamid Ibn Badis, Mostaganem. Afrique Science, 4, 1-20.

[25] Sahin, R., Demirboga, R., Uysal, U. and Gul, R. (2003) The Effects of Different Cement Dosage Slumps and Primice Aggregate Ratios on the Compressive Strength and Densities of Concrete. Cement and Concrete Research, 33, 1245-1249. https://doi.org/10.1016/S0008-8846(03)00048-6

[26] Fiori, B., Beaucour, A.L. and Ortola, S. (2004) Optimization of the Mechanical Behavior of Lightweight Aggregate Concrete by the Use of High Performances Cementations Matrixes. Symposium Fib (Ceb-Fip)/AFGC on Concrete Structures: the Challenge of Creativity, Avignon, 26-28 April 2004.

[27] Sampaio, Z.L.M., Martinelli, A.E. and Gomes, T.S. (2017) Formulation and Charac- 
terization of Structural Lightweight Concrete Containing Residues of Porcelain Tile Polishing Tire Rubler and Limestone. Ceramica, 63, 530-535.

https://doi.org/10.1590/0366-69132017633682139 